\title{
Quality of Work Life Among Women Police in Theni District
}

\author{
${ }^{1}$ K. NIVETHA, ${ }^{2}$ Dr. S. CHITRA \\ ${ }^{1}$ M.Phil Scholar, ${ }^{2}$ Principal \& Professor, Department of Commerce, Nadar Saraswathi College of Arts \\ \& Science, Theni, India.
}

\begin{abstract}
The concept of women working in Indian heritage environment has always been challenging and much more of those women working in police. A study of this research covered the challenges being faced by women police in Theni District. This research addressed as Quality of work life among women police. Women are actively participating in various economic activities and managing their roles in the police promptly. Quality of working life enables them to participate at all levels of the actively and effectively. . Police department is one of the most everywhere of the society. Police work involves protection of public life, safeguarding property through vital patrol techniques, enforcement of laws and ordinances in the place for which the police station is responsible. The present study makes an attempt to study the quality of work life of women police.
\end{abstract}

Keywords - Quality of Work, Women Police.

\section{INTRODUCTION}

Women in India enjoy only a lower status in the society and they can be considered as a needy section of the society. They were not uplifted the equal status in all walks of life, political, social, economical, educational society. Indian women have a great part to play in progress of the country, as the mental and physical contact of women with life is much more lasting and comprehensive than that of men. Presently, women are actively participating in various economic activities and managing their roles in the organization promptly. Their traditional role of home maker has been transformed into the new role of a professional woman. In India, a number of women have successfully broken the glass ceiling and attained top positions. Quality of work life enables them to participate at all levels actively and effectively in constructing an organisational environment, methods and outcomes. It involves job security, working conditions, compensation, employment opportunity, involvement and empowerment, and other organisational factors. Police Department is one of the most universally organizations of the society. The women police personnel most of the time work under stress due to work load, extended duty hours, political pressures, personal/family problems etc. Attempts to understand and tackle stress and strain in the police context might be compromised from the start if the broader work context is not taken into account. The present study makes an attempt to study the quality of work life of women police, and the working policies and practices followed by the police department for women police.

\section{HISTORY OF WOMEN POLICE IN THENI DISTRICT}

$>$ The Theni All Women Police Station has secured the 4th rank at the national level among best performing police stations in the country.

$>$ As per the list released by the Ministry of Home Affairs, the station is the only entrant from Tamil Nadu among 10 stations. The Inspector of Police attached to the AWPS Theni, P. K. T. Mangaiyar Thilagam, said that the station covers two subdivisions, including Theni and Periyakulam and hence gets a lot of petitions, which are redressed and disposed immediately.

$>\quad$ "We have a strength of 30 and all of us together make sure that no complaint go unattended. We never delay any petition and attend to it promptly. We also give counseling to affected women in rural areas and do awareness drives," she said.

\section{OBJECTIVES OF THE STUDY}

The following are the main objectives of the present study,

1. To examine the socio-economic profile of the women police and their quality of work life.

2. To know whether the respondents are able to balance the work life and family life.

3. To know about the factors of quality of working life.

4. To assess the various factors contributing to improve the work life balance of women police. 


\section{STATEMENT OF THE PROBLEM}

Work life balance is one of the major problems of women working is the police department on the whole, the characteristics of work and family role are greatly altered, night shifts long working hours have introduced significant distortions is the family which naturally affect the mental balance of not only the women, but also her family members as well.

Work life balance of women police working in police department is always questionable. The needs to evaluate the level of work life balance of women police and their reasons to be either balanced or unbalanced are felt by the researcher and have the present study has been undertaken.

\section{SCOPE OF THE STUDY}

$>$ The research study is aims at to understand the quality of working life of women police.

$>$ Quality of work life refers to the relationship between women police and their work environment.

$>$ That includes better working conditions, equal employment opportunity, adequate and fair wage, and so on.

$>$ The researcher could analyze the various factors which can help to overcome the problem both in work and family interference and to identify the means to balance the work life of the employees as well as own.

\section{REVIEW OF LITERATURE}

Reddy et.al (2010) conducted the study titled, "Work-Life Balance among Married Women Employees". They mentioned the factors influencing Work Family Conflict (WFC) and Family Work Conflict (FWC) and also observed its relation with stress.

Kretschmer et.al (2011) in their article titled "Work-Life Balance, Management Practices and Productivity", had shown a useful firm specific measure of Work Life Balance. They investigated that the pessimists' argument that "Anglo-Saxon" management practices were negatively associated with worse WLB was rejected. As they observed that optimists suggested that there was a positive association with work life balance. Additionally, the pessimists' theory that competition was inevitably bad for workers' Work Life Balance was also rejected: there was no significantly negative relationship. Further they emphasized more on the relationship between the WLB and productivity. They viewed that WLB would improve productivity was also rejected: there was no such relationship between productivity and WLB

Pandey (2015) mentioned in his study titled: "A Review of Work-Life Balance Practices Prevalent in Public Sector Undertakings in India" about the review of work life balance, practices in India. He attempted to explore the work-life balance practices of selected public sector undertakings and their impact on organizational performance. He also 44 suggested that public sector organizations in India had realized that work-life balance practices were crucial for organizational performance.

Ofili et al. (2015) in their research study titled: "Assessment of Job Satisfaction, Job Stress and Psychological Health of Journalist in South-South, Nigeria", assessed the job 26 satisfaction, perception of job stress and psychological morbidity among journalists in a state in the Southern part of Nigeria.

\section{QUALITY OF WORK LIFE}

The Quality of work life (QWL) is a wide term covering an immense variety of programmes, techniques, theories and management style through which organisations and jobs are designed so as grant employee more autonomy, responsibility and authority than is usually done. A high quality of work life is essential for organizations to continue, to attract and retain employees. The reform of women's work life is still in its beginnings; most reformers have not treated it as a specific object with conditions and problems that are different from those of men's work life. Those fighting discrimination against women and struggling to erase women's inequality in the world of work often have not considered sufficiently the wider goal, the enhancement of women's overall working life.

The present era is an era of knowledge workers and the society in which we are living has come, to be known as knowledge society. The intellectual pursuits have taken precedence over the physical efforts.

Some knowledge workers work for more than 60 hours a week. As a result of this, their personal hobbies and interest clash with their work. Life is a bundle that contains all the strands together and hence the need to balance work life with other related issues.

One must have work in life to make it healthy. Gone are the days when the priority of employees used to be for physical and material needs. With the increasing shift of the economy towards knowledge economy, the meaning and quality of work life has undergone a drastic change.

\section{DUTIES OF WOMEN POLICE}

Women Police Stations have been created to attend to few police duties. They are

$>$ Registration and investigation of all dowry related cases.

$>$ Enquiry into all petitions preferred by women or on behalf of women.

$>$ Tracing of and looking after stray and run away female children.

$>$ Counseling in domestic disputes and discords.

$>$ Registration and investigation of IPC cases involving women.

$>$ Providing guard and escort for female prisoners. 


\section{RESEARCH METHODOLOGY}

Research methodology is a way to systematically solve the research problems. It may be understood as a science of studying how research is done scientifically. The research methodology adopted for the present study has been systematic and was done in accordance to the objectives set, which has been discussed in earlier pages.

\section{SAMPLING DESIGN}

The total number of 272 respondents was taken as the sample size from the entire population for the Theni district.

\section{Sample Size}

\begin{tabular}{|l|l|l|l|}
\hline S.No & Taluk & Population & Sample Size \\
\hline 1. & Theni & 199921 & 47 \\
\hline 2. & Periyakulam & 215979 & 59 \\
\hline 3. & Uttampalyam & 434813 & 62 \\
\hline 4. & Aundipatti & 212519 & 64 \\
\hline 5. & Bodi & 180789 & 40 \\
\hline Total & & $12,44,021$ & 272 \\
\hline
\end{tabular}

\section{FRAMEWORK OF ANALYSIS}

In the present study the researcher collect the primary data from the Women Police. The area selected for the study in Theni district. From the population sample size selected for the study was 272 respondents. For collection primary data the researcher used the questionnaire method. Researchers consist of different type's questions like, ranking of the item, Open ended respondents and Close ended respondents for analysis the collected primary data statistical tools like

\section{* Simple Percentage Analysis \\ * Garrett's ranking technique \\ * Likert Scaling Analysis \\ \# Correlation Analysis \\ \# Chi - square}

\section{SUMMARY OF FINDING}

This study has to be concluded with its findings, suggestions and conclusion. The major findings of the study have been mentioned below.

\section{SIMPLE PERCENTAGE ANALYSIS}

The study reveals the following:

* Majority of the respondents (39\%) belongs to the age group of 41-50 yrs.

* Majority of the respondents (70\%) are married.

* Majority of the respondents (57\%) having the education qualification of PG and above.
* Majority of the respondents $(75 \%)$ are head constable and constable.

* Majority of the respondents (52\%) having the experience of 10-20 years.

* Majority of the respondents (39\%) are belongs to the monthly income group of above Rs. 40000 .

\section{GARRETT'S RANKING TECHNIQUES}

Most important reason in professional life

Respondents have ranked first and second is "Health \& well being and Family Support". These two factors are most important in women professional life.

\section{LIKERT SCALING TECHNIQUE}

Most important factors are satisfied in Women Police

* Problem faced at work place - Unsatisfactory working condition is the first rank,

* Problem faced at home - Obstruct the family relationship is the first rank,

* Management of stress rising from work place Recreational facilities is the first rank,

* Work environment - Working condition is the first rank,

* Organisation culture - Proud of work is the first rank,

* Relation and co-operation - Work demand stress,

* Job satisfaction and job security - Compatible satisfied salary.

\section{CORRELATION ANALYSIS}

A) Personal factor and Study factor

* There is a Weak Positive Relationship between the Age and Work life balance

* There is a Positive Relationship between the Income and Work life balance

* There is a Strong Positive Relationship between the Designation and Work life balance

* There is a no Relationship between Hours and Work life balance

B) Study factor and Study factor

* There is a no Relationship between the Working place facilities and Work life balance

* There is a Weak Positive Relationship between the Better performance and Utilization of women police

* There is a Positive Relationship between Better performance and Stress Level

* There is a Strong Positive Relationship between Type of providing Job and Better performance

\section{Chi - Square Analysis}

On the basis of eight hypothesis are framed by the research scholar, the following findings are observed. 
* Age of the respondents have significant relationship with the level of satisfaction towards in Women Police.

* Marital status of the respondents has significant relationship with the level of satisfaction towards in Women Police.

* Educational qualification of the respondents has significant relationship with the level of satisfaction towards in Women Police.

* Designation of the respondents has significant relationship with the level of satisfaction towards in Women Police.

* Experience of the respondents has significant relationship with the level of satisfaction towards in Women Police.

* Income per month of the respondents has significant relationship with the level of satisfaction towards in Women Police. coping behavior", Journal of Police Psychology, vol. 3, 30-42, 1987.

[6] G.A. Adams, L.A. King and D.W. King, "Relationships of joband family involvement, family social support, andwork-family conflict with job and life satisfaction", Journal of Applied Psychology, vol. 81, no.,4, pp. 411-420, 1996.

\section{WEBSITES}

[7] www.researchgate.net

[8] www.ijstm.com

[9] WwW.scribd.com

\section{CONCLUSION}

Quality of work life is a system that promotes and maintains recruits satisfaction to improve working conditions and organisational effectiveness for Women Police. Overall, police work is not satisfactory for both men and women police. Especially, women police face various problems and difficulties in their job which are need to be resolved. She is playing multiple roles, and cannot possible do equal justice to her roles. At the workplace women police need better working conditions and other facilities, which help to improve her quality of work life. Therefore, by improving working conditions, job security, providing adequate and fair compensation, equal opportunity, and by other measures women police may get satisfaction in their work, which increases the efficiency and effectiveness of work of women police at the workplace.

\section{REFERENCE}

[1] Frone, Michael." Work-family balance". Handbook of occupational health psychology.pp.143-162

[2] Greenhaus, JH. Collins, KM., \& Shaw, JD. "The Relation Between Work-Family Balance and Quality of Life', Journal of Vocational Behavior. DOI: 10.1016/S0001- 8791(02)00042-8.

[3] PrashantLele, D 2018, "Quality of Work Life of Police Constables with Special Reference to Wellness. [online] Iosrjournals.org. Available at: http://iosrjournals.org/iosr-jbm/papers/Vol16issue11/Version-4/G0161144651.pdf[Accessed 30 Oct. 2018].

[4] M.L. Dantzer, "Police-related stress: A critique for future research", Journal of Police and Criminal Psychology, vol. 3, no.3, pp. 43-48, 1987.

[5] S.R. Band and C.A. Manuele, "Stress and police officer performance: An examination of effective 